\title{
I n vitro Antimicrobial Comparison of Taif and Egyptian Pomegranate Peels and Seeds Extracts
}

\author{
Ahmed Gaber ${ }^{1,2}$, Mohamed M. Hassan*1,3, El-Dessoky S. Dessoky ${ }^{1,4}$, Attia O. Attia ${ }^{1,4}$ \\ ${ }^{1}$ Scientific Research Deanship, Biotechnology and Genetic Engineering Unit, Taif University, KSA. ${ }^{2}$ Departmentof Genetics, Faculty of Agriculture, Cairo \\ University, Egypt. ${ }^{3}$ Department of Genetics, Faculty of Agriculture, Minufiya University, Egypt. ${ }^{4}$ Department of Plant Genetic Transformation, Agricultural \\ Genetic Engineering Research Institute (AGERI), Agricultural Research Centre (ARC), Giza, Egypt.
}

\section{ARTICLE INFO}

Article history:

Received on: 10/03/2015

Revised on: 03/04/2015

Accepted on: 16/04/2015

Available online: 27/04/2015

Key words:

Punica granatum, antibacterial activity, Peels and seeds extracts and RepPCR.

\begin{abstract}
Punica granatum are utilized by local people as the part of their meal. Peoples supposed to consume Punica granatum seed and their peel was thrown as waste. Present study was designed to evaluate the antibacterial activity of the DMSO, ethanol and methanol extracts of Egyptian and Taif cultivars of Punica granatum peel and seeds extracts against five opportunistic pathogens namely Staphylococcus aureus, Pseudomonas sp. and Bacillus $s p$. (as a gram positive bacteria), Escherichia coli and Aeromonas hydrophila (as a gram negative bacteria). The antimicrobial activity of plant peels and seeds extracts were compared with that of Streptomycin, as reference antibiotics. Evaluations were based on the zone of inhibition using agar well diffusion assay. The inhibitory activity was found to be dose dependent. The methanol extract of the peels from the two cultivars at $15 \mathrm{mg} / \mathrm{ml}$ dosage were found to be active antimicrobials against all the test microorganisms. While, the maximum antimicrobial activity for the seeds extracts were reported at $60 \mathrm{mg} / \mathrm{ml}$. Escherichia coli was reported to have significant susceptibility against most of the extract followed by Staphylococcus aureus and Pseudomonas $s p$. Additionally, we evaluated the effect of the peels and seeds extract on the DNA damage of the bacterial genome using the repetitive element PCR analysis technique (Rep-PCR). The Rep-PCR results significantly showed that there are a polymorphic numbers of genetic bands, which were found in $E$. coli treated bacteria and absent in the untreated bacteria. This study indicates that aqueous DMSO, methanol and ethanol extracts of peels and seeds of the two cultivars of Punica granatum may be utilizes as a potential source of antimicrobial and mutagen agents.
\end{abstract}

\section{INTRODUCTION}

Punica granutam, also well known by different local name like dalim, anar and pomegranate, is belongs to the family of Punicaeae [1]. Punica granatum are widely available in Mediterranean basin and Southern Asia in warm environment [2]. Different part of pomegranate like bark, leaves, immature fruits, and fruit rind have some medicinal importance [3]. Various investigations were carried out to determine antioxidant, anticarcinogenic, and anti-inflammatory properties of pomegranate constituents [3-7]. Moreover, pomegranate is used in several systems of medicine for a variety of ailments. It is considered "a pharmacy unto itself" in Ayurvedic medicine and is used as an antiparasitic agent [8] a blood tonic [9] and to heal aphthae, diarrhea, and ulcers [10-11]. Pomegranate also serves as a remedy for diabetes in the Unani system of medicine practiced in the Middle East and India [12]. The current explosion of interest in pomegranate as a medicinal and nutritional product is

\footnotetext{
* Corresponding Author

Email: khyate_99@yahoo.com
}

evidenced by a MedLine search from 2000 to present, revealing over 130 new scientific papers pertaining to its health effects. Between 1950 and 1999 only 25 such publications appear on MedLine [13]. The potential therapeutic properties of pomegranate are wide-ranging and include treatment and prevention of cancer, cardiovascular disease, diabetes, dental conditions, erectile dysfunction, and protection from ultraviolet (UV) radiation. Other potential applications include infant brain ischemia, Alzheimer's disease, male infertility, arthritis, and obesity [4].

Over the past decade, significant progress has been made in establishing the pharmacological mechanisms of pomegranate and the individual constituents responsible for them. Extracts of all parts of the fruit appear to have therapeutic properties [8] and some studies report the bark, roots, and leaves of the tree have medicinal benefit as well. Additionally, this plant is reported to have excellent antibacterial, antifungal, antiprotozoal and antioxidant properties [14-16].

Numerous phytochemical constituents have been reported to be present in different parts of the pomegranate plant making it pharmacologically precious [17]. 
The major class of pomegranate phytochemicals is the polyphenols (phenolic rings bearing multiple hydroxyl groups) that predominate in the fruit. Pomegranate polyphenols include flavonoids (flavonols, flavanols and anthocyanins), condensed tannins (proanthocyanidins) and hydrolysable tannins (ellagitannins and gallotannins). Hydrolyzable tannins (HTs) are found in the peels (rind, husk, or pericarp), membranes and piths of the fruit [18].

HTs are predominant polyphenols found in pomegranate juice and account for $92 \%$ of its antioxidant activity.

The aims of the present study were to compare the antimicrobial activity of two pomegranate (Punica granatum L.) cultivars (Egyptian and Taif) on the level of peels, seeds and the extract type (Demso, Ethanol and Methanol).

\section{MATERIALS AND METHODS}

\subsection{Bacterial strains}

Five food-borne bacterial species were used in this study (Escherichia coli, Staphylococcus aureus, Aeromonas hydrophila, Pseudomonas sp. and Bacillus sp.) to evaluate the antibacterial activity. The bacteria were obtained as kindly gift from the microbial genetics Lab., Biotechnology and Genetic Engineering Unit, Scientific Research Center, Taif University, KSA.

\subsection{Plant materials}

The pomegranate (Punica granatum L.) fruits were collected from Taif vegetable market, Taif governorate, KSA. Fresh fruit were washed well with running water and hand-minced into small pieces to get peel and seeds, grinded in liquid nitrogen and kept in freezer until used. The freeze powder of seeds was extracted in DMSO, methanol and ethanol to get the extraction.

\subsection{Determination of antibacterial activity}

The agar-well diffusion method was employed for determination of antibacterial activities [19]. All bacteria were suspended in sterile water and diluted to $10^{6} \mathrm{CFU} / \mathrm{ml} .200 \mu \mathrm{l}$ of the suspension was spread onto the surface of NA medium. Wells (4.6 $\mathrm{mm}$ in diameter) were cut from the agar with a sterile borer. The concentrations of the peel $(15,30 \mathrm{mg} / \mathrm{ml})$ and seeds $(30,60$ $\mathrm{mg} / \mathrm{ml}$ ) extracts were applied. Negative controls were prepared using water. The artificial Streptomycin with a concentration of $(1.2 \mu \mathrm{g} / \mathrm{ml})$ was used as positive reference standards to determine the sensitivity of each microbial species tested and to compare the relative percent of antibacterial activity. The inoculated plates were incubated at $37{ }^{\circ} \mathrm{C}$ for $24 \mathrm{~h}$. Antibacterial activity was evaluated by measuring the diameter of inhibition zone (DIZ) of the tested bacteria. DIZ was expressed in millimeters. All tests were performed in triplicate.

\subsection{Repetitive sequence analysis of the genomic DNA}

The bacterial genomic DNA was extracted from bacterial strain using the procedure explained by the Jena Bioscience bacterial DNA preparation kit (Germany). For repetitive sequence analysis, PCR conditions for bacterial isolates in the present investigations were standardized. Five repetitive sequence primers were used to amplify genomic DNA of the isolates. The five primers sequences were as following Rep 12 (5'AGAGAGAGAGAGAGAGC-3'), Rep 18 (5'ACACACACACACACACG-3'), Rep 19 AGAGAGAGAGAGAGAGTT-3'), BOX A1 (5'CTACGGCAAGGCGACGCTGACG-3'), and (GTG) $)_{5}$ (5'GTGGTGGTGGTGGTG-3'). Following the experiments for optimization of component concentrations, PCR amplification of repetitive sequence primers were carried out in $25 \mu \mathrm{l}$ volume containing $1 \mu \mathrm{l}(20 \mathrm{ng})$ of genomic DNA, $12.5 \mu \mathrm{l}$ of Go $\mathrm{Taq}^{\circledR}$ Green Master Mix, Promega, USA. $1 \mu$ l of primer (20 p.mol), deionized distilled water (up to a total volume of $25 \mu \mathrm{l}$ ). For DNA amplification, the $\mathrm{C} 1000^{\mathrm{TM}}$ Thermo Cycler Bio-Rad, Germany, was programmed under the conditions involving denaturation at $94^{\circ} \mathrm{C}$ for $5 \mathrm{~min}$; 30 cycles of denaturation at $94^{\circ} \mathrm{C}$ for $1 \mathrm{~min}$, primer annealing at $52^{\circ} \mathrm{C}$ for $45 \mathrm{Sec}$ and primer extension at $72^{\circ} \mathrm{C}$ for $2.5 \mathrm{~min}$; final extension step at $72^{\circ} \mathrm{C}$ for $10 \mathrm{~min}$. Amplification products was separated in $1.5 \%$ agarose using TAE buffer, for 1.5 $\mathrm{h}$ at 100 volt, visualized under UV light after staining in $0.2 \mu \mathrm{g} / \mathrm{ml}$ ethidium bromide and photographed using Bio-Rad Gel documentation system (Germany).

\subsection{Statistical analysis}

All experiments were repeated three times. The growth turbidity of the three tested strains treated with different concentrations of pomegranate extract was calculated by one way ANOVA for the relationship between the growth turbidity and the concentrations of crude extract Both Microsoft Excel 2007 and SPSS (version 16) were used in such analysis.

\section{RESULTS}

\subsection{Antimicrobial activity of $\boldsymbol{P}$. granatum extracts against tested organisms}

The Agar well diffusion method was used in this study to assess the antimicrobial activity of two cultivars of $P$. granatum (Egyptian and Taif) using peel and seeds extract [20]. This method allows better diffusion of the extracts into the medium thus enhancing contact with the organisms.

The antimicrobial activity as a clear inhibition zone (in mm diameter) of DMSO, methanol and ethanol extracts of $P$. granatum peels at the concentrations of $15 \mathrm{mg} / \mathrm{ml}$, while, seeds extracts was at concentration of $60 \mathrm{mg} / \mathrm{ml}$. The two extracts were used against five pathogenic organisms, Escherichia coli, Staphylococcus aureus, Aeromonas hydrophila, Pseudomonas sp. and Bacillus sp., and the data are presented in Table 1 and 2 . The results showed that the peel extracts at final concentrations of $15 \mathrm{mg} / \mathrm{ml}$ for the two cultivars were active against the five types of microorganism, while, at the same concentration for the seed extracts was not efficient to kill any types of treated microorganism (Figure 1). On the other hand, the final concentration of $60 \mathrm{mg} / \mathrm{ml}$ of seed extracts was effective to kill the treated microorganism (Figure 2). 

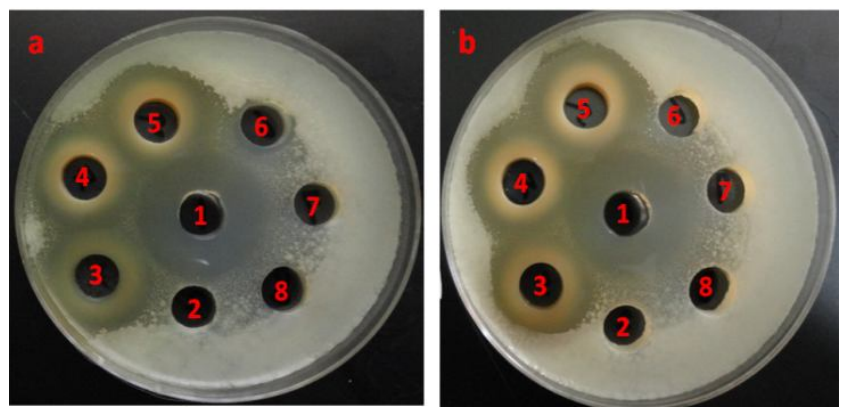

Fig. 1: Inhibition zone of different extraction types (Egyptian and Taif) of pomegranate peel and seeds extracts against $A$. hydrophila. a; Egyptian pomegranate and b; Taif pomegranate. $1=1.2 \mu \mathrm{g} / \mathrm{ml}$ of Streptomycin, $2=$ distilled water as a negative control, $3=$ DMSO peel extract $(15 \mathrm{mg} / \mathrm{ml}), 4=$ Methanol peel extract $(15 \mathrm{mg} / \mathrm{ml}), 5=$ Ethanol peel extract $(15 \mathrm{mg} / \mathrm{ml}), 6=$ DMSO seeds extract $(15 \mathrm{mg} / \mathrm{ml}), 7=$ Methanol seeds extract $(15 \mathrm{mg} / \mathrm{ml})$ and 8 $=$ Ethanol seeds extract $(15 \mathrm{mg} / \mathrm{ml})$.
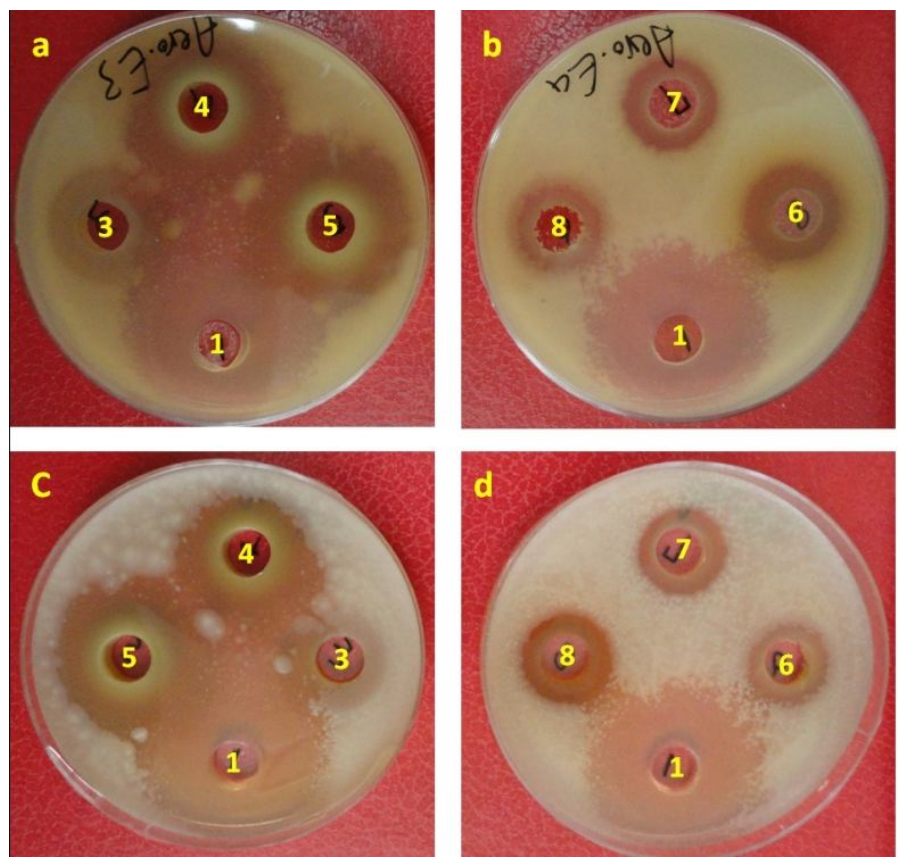

Fig. 2: Inhibition zone of different extraction types (Egyptian and Taif) of pomegranate peel and seeds extracts against A. hydrophila. a,b ; Egyptian pomegranate and c,d ; Taif pomegranate. $=1.2 \mu \mathrm{g} / \mathrm{ml}$ of Streptomycin, $3=$ DMSO peel extract $(15 \mathrm{mg} / \mathrm{ml}), 4=$ Methanol peel extract $(15 \mathrm{mg} / \mathrm{ml}), 5=$ Ethanol peel extract $(15 \mathrm{mg} / \mathrm{ml}), 6=$ DMSO seeds extract $(60 \mathrm{mg} / \mathrm{ml}), 7=$ Methanol seeds extract $(60 \mathrm{mg} / \mathrm{ml})$ and $8=$ Ethanol seeds extract $(60 \mathrm{mg} / \mathrm{ml})$.

The results also indicated that the ethanol was the best solvent for extracting antimicrobial substances from the peel and the seed of this plant compared to methanol and DMSO ( Table 1, 2 and Figure 1 and 2). Interestingly, Escherichia coli, Pseudomonas sp. and Bacillus sp. were mostly susceptible to peel and seeds extracts of Egyptian cultivar than Taif cultivar (Table 1 and 2). It can be suggested that Staphylococcus aureus was the most resistant organisms to the concentrations of $15 \mathrm{mg} / \mathrm{ml}$ of the ethanol peel extract of Egyptian cultivar $(21 \mathrm{~mm})$. Maximum activity of ethanol extract for the peel of Egyptian cultivar was seen against Pseudomonas sp $(33 \mathrm{~mm})$. Poor inhibitory effect was detected against. The plant extracts compared favorably with the standard antibiotic Streptomycin at a final concentration of 1.2 $\mu \mathrm{g} / \mathrm{ml}$ (Table 1 and 2).

Table 1. Diameter of inhibition zone (DIZ) in $\mathrm{mm}$ of five bacterial strains which caused by peel aqueous extract of Taif and Egyptian pomegranate.

\begin{tabular}{llllllll}
\hline \multirow{2}{*}{ Isolates } & DIZ & \multicolumn{3}{c}{ DIZ of Taif extract } & \multicolumn{3}{c}{ DIZ of Egyptian extract } \\
\cline { 3 - 8 } & Strep & D & M & E & D & M & E \\
\hline E. coli & 33 & $23^{\mathrm{d}}$ & $26^{\mathrm{c}}$ & $25^{\mathrm{c}}$ & $26^{\mathrm{c}}$ & $30^{\mathrm{b}}$ & $32^{\mathrm{a}}$ \\
S. aureus & 25 & $21^{\mathrm{b}}$ & $24^{\mathrm{a}}$ & $25^{\mathrm{a}}$ & $21^{\mathrm{b}}$ & $19^{\mathrm{c}}$ & $21^{\mathrm{b}}$ \\
A. hydrophila & 26 & $25^{\mathrm{b}}$ & $25^{\mathrm{b}}$ & $27^{\mathrm{a}}$ & $22^{\mathrm{c}}$ & $22^{\mathrm{c}}$ & $23^{\mathrm{c}}$ \\
Pseudomonas $s p$. & 30 & $20^{\mathrm{d}}$ & $30^{\mathrm{b}}$ & $27^{\mathrm{c}}$ & $30^{\mathrm{b}}$ & $32^{\mathrm{a}}$ & $33^{\mathrm{a}}$ \\
Bacillus sp. & 30 & $25^{\mathrm{c}}$ & $26^{\mathrm{c}}$ & $27^{\mathrm{b}}$ & $24^{\mathrm{d}}$ & $28^{\mathrm{b}}$ & $30^{\mathrm{a}}$ \\
Means & 28.8 & 22.8 & 26.2 & 26.2 & 24.6 & 26.2 & 27.8 \\
\hline
\end{tabular}

Table 2. Diameter of inhibition zone (DIZ) in $\mathrm{mm}$ of five bacterial strains which caused by seeds aqueous extract of Taif and Egyptian pomegranate.

\begin{tabular}{llllllll}
\hline \multirow{2}{*}{ Isolates } & \multirow{2}{*}{$\begin{array}{c}\text { DIZ } \\
\text { of }\end{array}$} & \multicolumn{2}{c}{ DIZ of Taif extract } & \multicolumn{2}{c}{$\begin{array}{c}\text { DIZ } \\
\text { extract }\end{array}$} & of & Egyptian \\
\cline { 3 - 8 } & Strep & D & M & E & D & M & E \\
\hline E. coli & 33 & $19^{\mathrm{c}}$ & $18^{\mathrm{c}}$ & $21^{\mathrm{a}}$ & $20^{\mathrm{b}}$ & $21^{\mathrm{a}}$ & $22^{\mathrm{a}}$ \\
S. aureus & 25 & $19^{\mathrm{a}}$ & $18^{\mathrm{b}}$ & $19^{\mathrm{a}}$ & $17^{\mathrm{c}}$ & $18^{\mathrm{b}}$ & $19^{\mathrm{a}}$ \\
A. hydrophila & 26 & $17^{\mathrm{c}}$ & $18^{\mathrm{c}}$ & $20^{\mathrm{b}}$ & $20^{\mathrm{b}}$ & $20^{\mathrm{b}}$ & $22^{\mathrm{a}}$ \\
Pseudomonas sp. & 30 & $21^{\mathrm{b}}$ & $19^{\mathrm{c}}$ & $20^{\mathrm{b}}$ & $22^{\mathrm{a}}$ & $22^{\mathrm{a}}$ & $23^{\mathrm{a}}$ \\
Bacillus sp. & 30 & $21^{\mathrm{a}}$ & $21^{\mathrm{a}}$ & $22^{\mathrm{a}}$ & $17^{\mathrm{c}}$ & $19^{\mathrm{b}}$ & $20^{\mathrm{b}}$ \\
Means & 28.8 & 19.7 & 18.8 & 20.4 & 19.2 & 20 & 21.6 \\
\hline & & & & & & &
\end{tabular}

\subsection{The genetic effects of the Egyptian and Taif pomegranate peel and seeds extracts.}

In order to explore the stability of the genetic material, at the molecular level, in the treated bacteria as a results of the antimicrobial activities of the different concentrations of Egyptian and Taif pomegranate peel and seeds extracts, the changes in the bacterial genetic material due to the treatment of the plant extracts was evaluated using Rep-PCR analysis for genomic DNA. The Rep-PCR results showed that a lot of polymorphic numbers of the genetic bands, which were from the electrophoretic products of PCR for the treated E. coli bacteria strain compared with those of untreated bacteria (Tables 3 and Figures 3, 4, 5, 6, and 7).

Table 3: Polymorphic bands of each genetic primers and percentage of polymorphism in E. coli treated with different concentration of Egyptian and Taif pomegranate peel and seeds extracts.

\begin{tabular}{|c|c|c|c|c|c|}
\hline$\stackrel{\grave{D}}{\stackrel{\Xi}{\Xi}}$ & 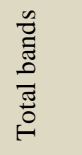 & 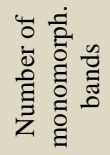 & 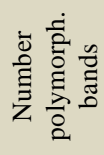 & 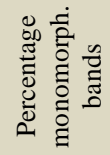 & 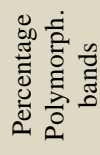 \\
\hline Rep 12 & 18 & 4 & 14 & 22 & 78 \\
\hline Rep 18 & 23 & 3 & 20 & 13 & 87 \\
\hline Rep 19 & 19 & 3 & 16 & 15.7 & 84.3 \\
\hline (GTG)5 & 30 & 1 & 29 & 3.3 & 9.7 \\
\hline BOX A1 & 31 & 0 & 31 & 0 & 100 \\
\hline Total & 121 & 11 & 110 & & \\
\hline
\end{tabular}

Table 3 illustrates that the highest number of polymorphic bands among treated E. coli was generated in reaction with the primer BOX A1 (31 polymorphic bands), and this is represented $100 \%$ of the total bands. Next, (GTG)5 primer was the second number of the highest number of polymorphic bands (29) that represent $96.7 \%$ of the total obtained bands (Tables 3). Interestingly, when we use Rep 12 as a primer with the genome 
of the treated $E$. coli strain with the plant peel and seeds extracts, we can obtain a unique positive bands at a molecular weight of 600, 1100 and 1800 bp (Figure 3).

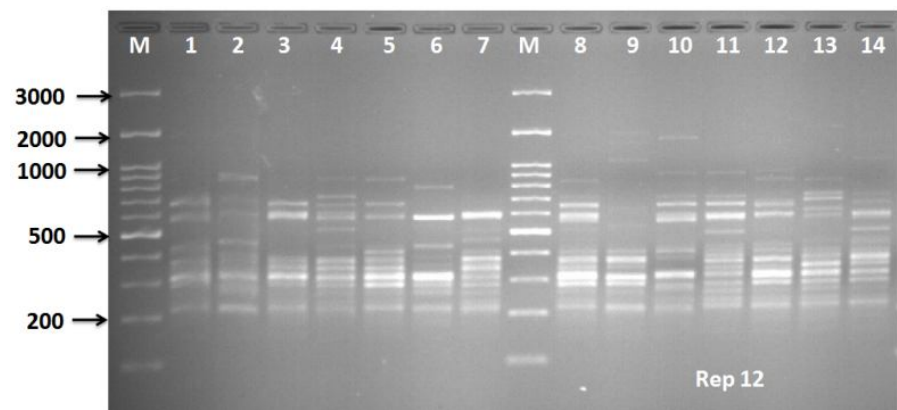

Fig. 3: Rep-PCR profile of treated E. coli strain generated with Rep primer No. 12 using different concentration of Taif peel extract (2-4), Taif seeds extract (5-7), Egyptian peel extract (9-11) and Egyptian seeds extract (12-14), M: is 100 bp DNA ladder, 1and $8=$ untreated $E$. coli. The concentrations of peel extract were $0.5,1$ and $1.5 \mathrm{mg} / \mathrm{ml}$, respectively. While, the concentrations of seeds extract were 1,2 and $3 \mathrm{mg} / \mathrm{ml}$, respectively.

Surprisingly, the clear band at the molecular weight of $2800 \mathrm{bp}$ in control $E$ coli strain (untreated bacteria) was absent in treated E coli strain (Figure 3). Also, the bands with molecular weight about 1900 and 2000 bp were showed as a positive unique band in the treated strain (Figure 4).

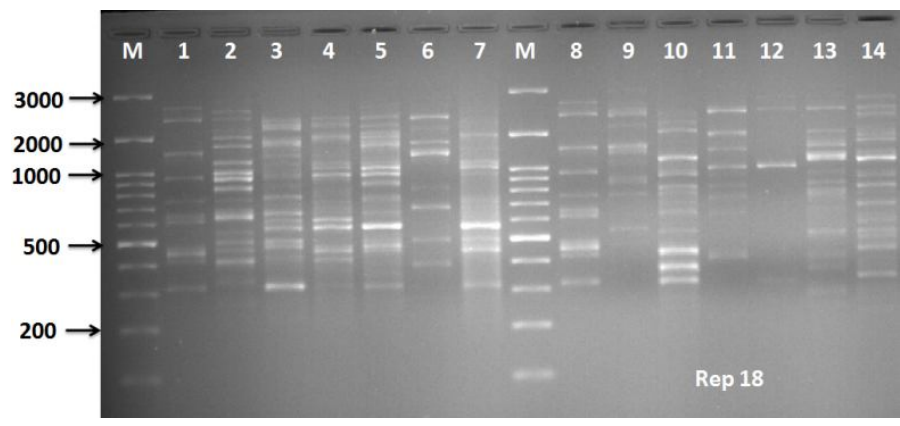

Fig. 4: Rep-PCR profile of treated E. coli strain generated with Rep primer No. 18 using different concentration of Taif peel extract (2-4), Taif seeds extract (57), Egyptian peel extract (9-11) and Egyptian seeds extract (12-14),. M: is 100 bp DNA ladder, 1 and $8=$ untreated $E$. coli. The concentrations of peel extract were $0.5,1$ and $1.5 \mathrm{mg} / \mathrm{ml}$, respectively. While, the concentrations of seeds extract were 1,2 and $3 \mathrm{mg} / \mathrm{ml}$, respectively.

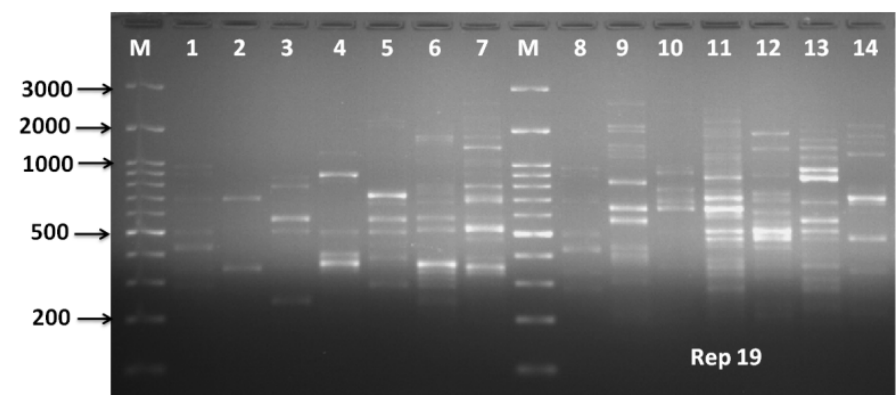

Fig. 5: Rep-PCR profile of treated E. coli strain generated with Rep primer No. 19 using different concentration of Taif peel extract (2-4), Taif seeds extract (5-7), Egyptian peel extract (9-11) and Egyptian seeds extract (12-14),. M: is 100 bp DNA ladder, land $8=$ untreated E. coli. The concentrations of peel extract were $0.5,1$ and $1.5 \mathrm{mg} / \mathrm{ml}$, respectively. While, the concentrations of seeds extract were 1,2 and $3 \mathrm{mg} / \mathrm{ml}$, respectively.
The primer Rep 19 showed the highest number of positive unique bands found in treated bacteria rather than untreated bacteria, such as bands with the molecular weight of about 2500, 2000, 1900, 360 and 240 (Figure 5).

Finally, the primers (GTG)5 and BOX A1 get a lowest number of monomorphic bands and most bands were common in treated and untreated bacteria (Figures 6 and 7).

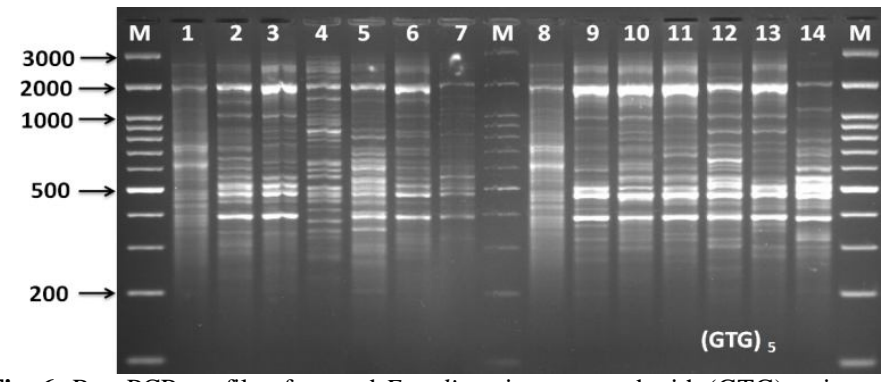

Fig. 6: Rep-PCR profile of treated $E$. coli strain generated with $(\mathrm{GTG})_{5}$ primer using different concentration of Taif peel extract (2-4), Taif seeds extract (5-7), Egyptian peel extract (9-11) and Egyptian seeds extract (12-14),. M: is $100 \mathrm{bp}$ DNA ladder, 1 and $8=$ untreated $E$. coli. The concentrations of peel extract were $0.5,1$ and $1.5 \mathrm{mg} / \mathrm{ml}$, respectively. While, the concentrations of seeds extract were 1,2 and $3 \mathrm{mg} / \mathrm{ml}$, respectively.

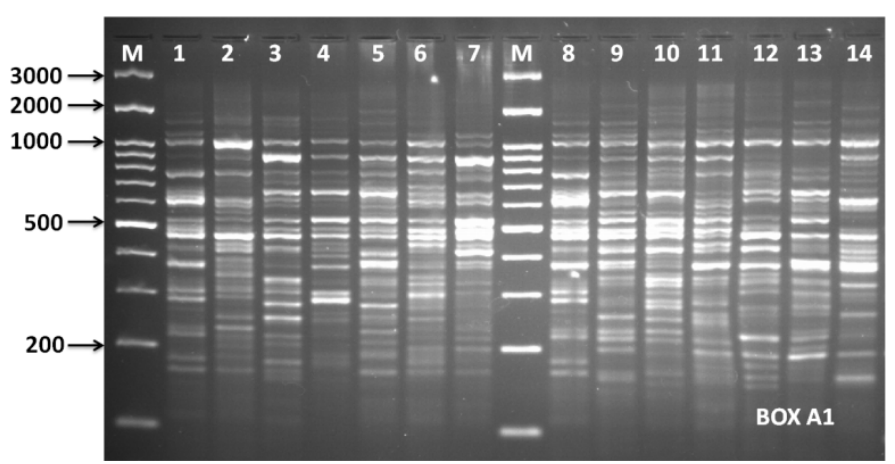

Fig. 7: Rep-PCR profile of treated E. coli strain generated with BOX A1 primer using different concentration of Taif peel extract (2-4), Taif seeds extract (5-7), Egyptian peel extract (9-11) and Egyptian seeds extract (12-14), M: is $100 \mathrm{bp}$ DNA ladder, 1 and $8=$ untreated $E$. coli. The concentrations of peel extract were $0.5,1$ and $1.5 \mathrm{mg} / \mathrm{ml}$, respectively. While, the concentrations of seeds extract were 1,2 and $3 \mathrm{mg} / \mathrm{ml}$, respectively.

\section{DISSCUSSION}

The peel and seeds of Punica granatum shows various therapeutic applications as antibacterial, antifungal, antioxidant, antitumor, antiviral, antimalarial and antimutagenic effects as reported by different authors [3-7]. In the present study, the antimicrobial activities of the Taif and Egyptian pomegranate of peel and seeds extracts against five types of microorganisms were examined and its potency was assessed by the presence or absence of inhibition zones and zone diameter. In addition, it was found that different concentration of Egyptian and Taif pomegranate of peel and seeds extracts is inversely proportionate to growth rate, which means that an increase in the dose and exposure time is met by a decrease in survival of treated microbe strains, whereas tropical effect increased as dose and exposure time increased. All these results are in general agreement with the rule mentioned 
[21]. Indeed, it is reported that the bark leaves, flowers and fruits of pomegranate are widely used as phytotherapeutic agents. Alcohol extracts of pomegranate fruits showed antibacterial activity when tested against $S$. aureus, E. coli and Shigella dysentriae [22]. Methanolic extracts of Punica granatum fruit rind to be active against all microorganisms tested in their study [23]. These results are in accordance to results obtained in the present study for bacteria wherein antibacterial activity was observed for all the five bacterial cultures tested [21] showed that methanol, ethanol, acetone and water extracts obtained from pomegranate were active and effective against the tested microorganisms ( $S$. aureus, E. coli, Salmonella typhi, Vibrio cholera, S. dysenteriae S. sonnei, S. flexneri and S. boydii), showing an inhibition zones of 12-31 mm. In these study, showing an inhibition zones of 12-19 $\mathrm{mm}$ against studied microorganism (Escherichia coli, Staphylococcus aureus, Aeromonas hydrophila, Pseudomonas sp. and Bacillus sp.). The antibacterial and antifungal activities of pomegranate peel extract (rind), seed extract, juice and whole fruit on some bacteria [14] and he found that the peel extract has shown highest antimicrobial activity compared to other extracts. Among the selected bacterial and fungal cultures, the highest antibacterial activity was recorded against Staphylococcus aureus [24] reported that $P$. garantum have antimicrobial activity against a range of Gram positive and negative bacteria.

In our study, the genetic effect of the pomegranate (Punica granatum L.) extract as a mutagenic agent was confirmed by rep-PCR. The results of this analyze revealed a polymorphic banding pattern when comparing between the untreated bacteria and those treated with different concentration of Egyptian and Taif pomegranate peel and seeds extracts (Figures 3, 4, 5, 6 and 7). This observation gives good evidence to the ability of pomegranate extract to induce point mutation as a result of deletion compromising at least one nucleotide as revealed by the disappearance of many genetic bands and change in primer matching sites as compared with untreated bacteria. These results suggesting molecular changes as a deletion or frame shift mutations in one or more loci which affect gene expression and interruption in biochemical pathways of DNA and protein synthesis consequently as Alkaloids in Punica granatum peel and seeds extracts often do. These results are consistent with the results obtained [25-28]. Some of the components of Punica granatum may act as intercalation agent or generates free radicals which are interacted with genomic DNA to account for the observed deletions, as suggested by similar results obtained [2930] in their study with Cryptolepis sangvinolehta and Aspergillus terreus. Moreover, the damage showed by the SEM images indicated the lethal effect of the high concentration of the R. stricta leave extract on treated bacteria [28]. Similarly, oregano and thyme essential oil exhibit strong antimicrobial properties against E. coli $\mathrm{O} 157: \mathrm{H} 7$ and observed cells were damaged when treated with essential oil using SEM and the damage in the cells was similar [31] and tried to explain the mechanism of action for essential oil components in bacterial cells. It was thought to be the degradation of the cell wall damage to cytoplasmic membrane proteins, the binding of proteins, leakage of cell contents, and coagulation of cytoplasm and depletion of the proton motive force.

In a conclusion, the Taif and Egyptian pomegranate peel and seeds extracts, proved to have antimicrobial activities against five bacterial species. This finding indicates the possibility of using the pomegranate peel and seeds extracts as a source of antibacterial compounds for treatment of infections caused by multi-drug resistant (MDR) bacterial pathogens. The antimicrobial activities of the pomegranate peel and seeds extracts could be explained, under low concentration treatment, as a compounds that work as a mutagenic agent that cause likely deletion mutations, and probably frame shift mutations, in the treated bacteria. Increase of the concentration and duration of the treatment are lethal for the treated bacteria as the consequences of cytoplasmic membrane damages.

\section{REFERENCES}

1. Anonymous. http://www.mpbd.info/plants/punica-granatum.php. (Accessed date: 3rd January 2013).

2. Parashar A. and Ansari A. A therapy to protect pomegranate (Punica granatum L) from sunburn. Pharmacie Globale. International Journal of Clinical Practice. 2012; 5: 1-3.

3. Neelam and Singh D. P. Punica granatum: A review on pharmacological and therapeutic properties. International Journal of Pharmaceutical Sciences and Research. 2012; 3: 1240-1245.

4. Jurenka J. M. T. Therapeutic Applications of Pomegranate (Punica granatum L.) - A Review. Alternative Medicine Review. 2008; 13:128-144.

5. Dipak G., Axay P., Manodeep C. and Jagdish K. V. Phytochemical and Pharmacological Profile of Punica granatum: An Overview. IRJP. 2012; 3: 65-68.

6. Hossain H., Ahmed T., Howlader M. S. I. , Dey S. K., Hira A., Ahmed A. Sen R. In vitro Antioxidant Potential from the Leaves of Punica granatum Linn. Grown in Bangladesh. International Journal of Pharmaceutical and Phytopharmacological Research. 2014; 2:160166.

7. Hajoori M., Naik M., Naik K. and Desai S. Evaluation of antimicrobial activity of Punica granatumpeel extracts using different solvent system. International Journal of Pharmaceutical Sciences and Methods. 2014; 4: 26-31.

8. Hamza R. Z., Abdel-Azez A. M. and Hussien N. A. Evaluation of the antioxidant potential for different extracts of Al-taif pomegranate (Punica granatum L.) induced by atrazine and malathion pesticides in liver of male albino mice. International Journal of Pharmaceutical Sciences. 2015; 7: 89-94.

9. Ahmed T. G., Belal K. S. and Salem A. G. Protective Effect of Pomegranate Peel Extract against Diabetic Induced Renal Histopathological Changes in Albino Rats. IOSR-JDMS. 2014; 10: 94105.

10. Al-Muammar M. N. and Khan F. Obesity: the preventive role of the pomegranate (Punica granatum). Nutrition. 2012; 28:595-604.

11. Kam A. L., Li K. M., Razmovski-Naumovski V., Nammi S., Shi J., Chan K. and Li G. Q. Acomparative study on the inhibitory effects of different parts and chemical constituents of pomegranate on $\alpha$ amylase and $\alpha$-glucosidase. Phytotherapy Research. 2013; 27:16141620 .

12. Saxena A. and Vikram N. K. Role of selected Indian plants in management of type 2 diabetes: a review. Journal of Alternative and Complementary Medicine. 2004; 10: 369-378.

13. Lansky E. P. and Newman R. A. Punica granatum (pomegranate) and its potential for prevention and treatment of inflammation and cancer. Journal of Ethnopharmacology. 2007; 109: 177-206. 
14. Dahham S. S., Ali M. N., Tabassum H. and Khan M. Studies on antibacterial and antifungal activity of pomegranate (Punica granatum L.). American-Eurasian Journal Agricultural and Environmental Science. 2010; 9: 273-281.

15. Inabo H. I. and Fathuddin M. M. In vivo antitrypanosomal potentials of ethyl acetate leaf extracts of Punica granatum against Trypanosoma brucei brucei, Advance in Agriculture and Biology. 2011; $1: 82-88$

16. Moussa A. M., Emam A. M., Diab Y. M., Mahmoud M. E. and Mahmoud A. S. Evaluation of antioxidant potential of 124 Egyptian plants with emphasis on the action of Punica granatum leaf extract on rats. International Food Research Journal. 2011; 18: 535-542.

17. Prakash C. V. S. and Prakash I. Bioactive chemical constituents from pomegranate (Punica granatum) juice, seed and peel a review. International Journal of Research in Chemistry and Environment. 2011; 1:1-18.

18. Wu X. , Cao G. and Prior R. L. Absorption and metabolism of anthocyanins in elderly women after consumption of elderberry or blueberry. Journal of Nutrition. 2002; 132: 1865-1871.

19. National Committee for Clinical Laboratory Standards. Performance standards for antimicrobial susceptibility testing, 12th informational supple- ment. Approved standard M100-S12. National Committee for Clinical Labo- ratory Standards, Wayne, Pa. 2002.

20. Omenka C. A. and Osuoha J. O. Antimicrobial potency of grapefruit seed extract on five selected pathogens. Nigerian Journal Microbiology. 2000; 14: 39-42.

21. Mathabe M. C., Nikolova R. V., Lall N. and Nyazema N. Z. Antibacterial activities of medicinal plants used for the treatment of diarrhea in Limpopo Province, South African Journal of Ethnopharmocology. 2005; 105: 286-293.

22. Ahmad I. and Beg A. Z. Antimicrobial and photochemical studies on 45 Indian medicinal plants against multi-drug resistant human pathogens. Journal of Ethnopharmocology. 2001; 74: 113-123.

23. Prashanth D. J., Asha M. K. and Amit A. Antibacterial activity of Punica granatum. Fitoterapia. 2011;72: 171-173.

24. Yehia H. M., Elkhadragy M. F. and Abd-Elmoneim A. E. Antimicrobial activity of pomegranate rind peel extracts. African Journal of Microbiology Research. 2011; 4: 3664-3668.
25. Adam S. E., AL-Farhan A. H. and AL-Yahya A. Effect of combined Citrullus colocynthis and Rhazga stricta use in Najdi sheep. The American Journal of Chinese Medicine.2000; 28:385-390.

26. Morita H., Awang K., Hadi A. H., Takeya K., Itokawa H. and Kobayashi J. Conformational analysis of rhazinilam and three dimensional quantitative structure-activity relationships of rhazinilam analogues. Bioorganic and Medicinal Chemistry Letters. 2005; 15:1045-50.

27. Gilani S. A., Kikuchi A., Shinwari Z. K., Khattak Z. I. and Watanab K. N. Phytochemical, pharmacological and ethnobotanical studies of Rhazya stricta Decne. Phytotherapy Research. 2006; 21: 301-307.

28. El-Tarras A. E., Hassan M. M. and El-Awady M. A. Evaluation of the genetic effects of the in vitro antimicrobial activities of Rhazya stricta leaf extract using molecular techniques and scanning electron microscope. African Journal of Biotechnology. 2013; 12: 3171-3180.

29. Ansah C., Khan A. and Gooderham N.J. In vitro genotoxicity of the West African antimalarial herbal Cryptolepis sanguinolenta and its major alkaloid cryptolepine. Toxicology. 2014; 208:141-147.

30. Baeshin N. A., Qari S.H., Sabir J. S. M. and ALhejin A. M. Biochemical and Molecular Evaluation of Genetic Effects of Rhazya stricta (Decne) Leafs Extract on Aspergillus terreus. Saudi Journal of Biological Sciences. 2008; 15: 25-33.

31. Burt S. A. Essential oils: their antibacterial properties and potential applications in foods- a review. International Journal of Food Microbiology. 2004; 94: 223-253.

\section{How to cite this article:}

Ahmed Gaber, Mohamed M. Hassan, El-Desoky S. El-Dosoky and Attia O. Attia, In vitro Antimicrobial Comparison of Taif and Egyptian Pomegranate Peels and Seeds Extracts. J App Biol Biotech. 2015; 3 (02): 012-017. 